\title{
The Effectiveness Of Discovery Learning Model To Train The Science Process Skills Of Man Students On The Simple Harmonic Motion Material
}

\author{
Zefry Ardi Ferdiansah", Elok Sudibyo*, Munasir* \\ Science Education, Post Graduate, State University of Surabaya \\ DOI: 10.29322/IJSRP.10.02.2020.p9823 \\ http://dx.doi.org/10.29322/IJSRP.10.02.2020.p9823
}

\begin{abstract}
This study aims to produce effective learning devices with the discovery-learning model to train the students' science process skills on the Material of simple harmonic motion in $\mathrm{X}$ grade students at MAN Sidoarjo. The trial design used one group of pretest-posttest design. Data collected in the form of the effectiveness of learning devices through data analysis techniques done in qualitative and quantitative descriptive. The results showed that the effectiveness of learning devices reviewed from the average of $\mathrm{N}$ gain in X IPA 2 grade was a medium category, the average of $\mathrm{N}$ gain in X IPA 5 grade was a medium category and the average of $\mathrm{N}$ gain in X IPA 6 grade was high-category. The student's responses to the device and the implementation of learning were very positive with excellent categories in these three classes. Based on the research results, it concluded that learning devices by the discovery-learning model developed effectively to train the students' science process skills.
\end{abstract}

Index Terms- Discovery learning, science process skills, simple harmonic motion

\section{INTRODUCTION}

$I^{n}$ $\mathrm{n}$ the face of competitions that are increasingly difficult to have a major concern about the skills of the $21^{\text {st }}$ century, such as life and career skills, learning and innovation skills, information media and technology skills (Bernie trilling and Charle Fadel, 2009) [12]. When we apply the skills to the education universe will be reflected in science process skills. According to (Carin, 1993) that "knowing science is more than knowing content, it is also knowing how together evidence and how to relate evidence to interpretation [1].

Based on the results of observations in MAN Sidoarjo mainly for learning devices on the previous material such as syllabus that there is not time allocation, learning sources, and learning media in accordance with Permendikbud No. 22 the year 2016 [7]. The learning material does not explain the facts, concepts, principles, and procedures in detail. The students' teaching books (BAS) are not available yet related to the exercises for checking the students ' comprehension concretely and the glossary is unavailable with the least physical facts around the learning materials delivered on BAS. LKS is not made by teachers if the teachers want to make an experiment then LKS will be taken from BAS which the indicators and objectives do not correspond with RPP and the syllabus that has been created from the beginning. The teachers do not make the science process skills tests and to complete the skill score the teachers compare skill and knowledge score.

In addition, the students' ability in solving the daily test of the previous material in the 2018/2019 academic year was also low; there were many students who got a score below the Minimum Mastery Criterion (KKM), 25\% of the students who reached KKM in 75. This case is in line with the results of previous research of science process skills that showed the results of each indicator skills of the science process were still weak and among them observe $57 \%$, identify the variable $61 \%$ and predict $40 \%$ with 11 students from 37 that were complete with KKM in XI IPA grade. According to Hosnan (2014), doing discovery learning, students are encouraged to learn most through their own active involvement by concepts and principles, and teachers encourage students to have experience and conduct experiments probably to discover principles for themselves [6]. The description of Discovery learning and skills of the scientific process in accordance with the opinions of previous research, according to Ciptaning (2018) concluded Discovery learning can improve students' science process skills such as observing, communicating, classifying and concluding at SMAN 1 Punggur [2]. Rizal (2019) argues that the Discovery learning model can improve students' science process skills such as observing, measuring, communicating and making conclusions on the Senior High School in Bandung [10].

Based on the application of Discovery learning in the learning process to practice the skills of the science process requires suitable learning devices. Therefore, it is necessary to develop learning devices to implement a model involving students in learning activities, namely Discovery learning. To conduct this research, the researcher took the title:

"The Effectiveness of Discovery Learning Model to Train the Science Process Skills of MAN Students on the Simple Harmonic Motion Material".

\section{RESEARCH METHODS}

Research conducted was a type of development research because it aims to develop learning devices by the Discovery learning model that is effective to practice the students' science process skills of MAN Sidoarjo on the Material of motion simple 
harmonics. In the process of developing learning devices, there are three stages of development adapted from Plompo \& Nieveen (2010), namely, preliminary research, prototyping stage (development phase) and assessment phase (assessment phase) [8]. The effectiveness of learning devices was observed from the results of students' science process and response skills. The results of the assessment of science process skills acquired using the test method. Based on Permendikbud No. 23 of 2016, the skill assessment is an activity undertaken to measure the students' ability to apply knowledge in performing certain tasks [7]. The skill value category on MAN Sidoarjo divided into four kinds, when the value is less than 75 including as the less category, the value is between 75-83 including as enough category, the value is between 84-92 including as the good category and the value is between 93-100 including as the excellent category. The skill aspects in MAN Sidoarjo is complete when fulfilling the KKM 75.

The learning influence on students' science process skills was measured using normalized gain analysis (Hake,1999) [5]. The normalized gain criterion was divided into three types when the normalized gain was less than 0.30 including as low criteria when normalized gain was between 0.30 and 0.70 then including as moderate criteria and when the normalized gain was over 0.70 including as height. The students' response was the students' opinion of the learning activity component. The students' responses were measured using a questionnaire filled by students. The students' response was using the interpretation criteria scale adapted from Riduwan (2002) [9]. The criteria were divided into 5 , when $0 \%-20 \%$ including as very less, $21 \%-40 \%$ including as less, $41 \%-60 \%$ including as enough, $61 \%-80 \%$ including as good and $81 \%-100 \%$ including as very well.

\section{RESULTS AND DISCUSSION}

The Science process skills test was applied before and after the learning process. The science process skills were trained on students such as observing skills, variable identifying skills, predicting skills, experimental planning skills and data analyzing skills. The result of pretests and posttests of science process skills in table 1 was used to see students who were complete KKM or not.

Table 1: The Results of Pretest and Posttest KPS

$\begin{array}{llll}\text { Observing } & \text { XIPA 2 } & \text { X IPA 5 } & \text { XIPA 6 } \\ \text { Aspect } & & 31 & 37 \\ \text { Pretest } & 36 & 80 & 83 \\ \text { Posttest } & 76 & 0,70 & 0,73 \\ \text { N Gain } & 0,61 & \end{array}$

Table 1 showed that the average results of students' pretests overall were not completed by KKM as a fewer category. The average result of students ' posttest of X IPA 2 grade was 76, which stated to complete KKM as sufficient category, and $N$ Gain was 0.61 as medium category, while the average result of students' posttest X IPA 5 grade was 80 who expressed complete KKM as enough category, as well as N Gain, was 0.70 as medium category. Moreover, the average result of students' posttest X IPA 6 grade was 83 , which complete KKM as the good category and $N$ Gain was 0.73 as the high category. The improvement was between pretests to posttest was caused by Discovery learning model applied. Where Discovery learning concentrated learning on students through interaction between students, one of them was in a discussion. It was in accordance with Vygotsky's theory that emphasizes teaching on cooperative learning based on activity and discovery. Therefore, applying discussions, students' active experiences, and the material students have learned, the basic concepts were formed. According to the concepts of Cognitivism, Piaget's concept was formed from schemes, assimilation, and relevant accommodation, while according to Bruner the basic concept can be formed from discovery learning that focuses on the students' active experience.
From the exposure, data can be concluded that the skills of the students' science process got improvement after learning by Discovery learning model on the simple harmonic motion Material that was the original average pretests in X IPA 2 grade was 36, X IPA 5 grade was 31 and X IPA 6 grade was 37. After applying learning from the researcher, the average result of the posttest in X IPA 2 grade was 76, X IPA 5 grade was 80 and X IPA 6 grade was 83. This case corresponded to Hafid (2017) concluded the average value of $N$ gain increased science process skills that receive learning using Discovery learning was significantly greater than the students who received the learning Conventional [4]. Whereas according to Rizal (2019) stated that the implementation of Discovery learning can improve the basic skills of Senior High School students' science processes in Bandung based on the higher $N$ gain [10]. Sati (2017) concluded the implementation of the Discovery learning model improved the science process skills in VII B grade on State Junior High School 10 in Bengkulu with the average was 81.79 as the good category [11].

The students' response was the students' opinion or assessment as the component of learning activity. The student's responses were measured using the students' response questionnaire given after the end of the learning process. The 
students' responses were expressed very well with the acquisition of $89 \%$ in X IPA 2 grade, $90 \%$ in X IPA 5 grade and $95 \%$ in X IPA 6 grade stated yes to the statement on the questionnaires.

Table 2: The Result of Students' Response to the Questionnaire

Yes Answer (\%)

No

Statement

XIPA2 XIPA5 XIPA6

1

2

3

experiment

The learning done gives the opportunity to

5 identify variables that affect the experiment

6 The learning activities by experiments can help understand harmonic motion material

Discussion and experiment activities can provide

7 new experience and knowledge

The learning activities can train to analyze the

8

experimental data

The experiment activities can help to cultivate

9 the predicting skills based on the experiment results

The steps to work on LKS are easy to

10 understand

The students' learning books and LKS are easy

11

to understand and interesting

The students' learning books help the students to

12

13

The material in the learning book relates to daily

life understand the simple harmonic motion material 


\begin{tabular}{lccc}
\hline You are more enthusiasm on learning in the & & & \\
classroom & 87 & & 90 \\
Average & 89 & 90 & 95 \\
\hline
\end{tabular}

The students' response sheet consists of 14 students' statements stating the students' greatest response to no.7, which states the discussion and trial activities provide new experience and knowledge of $97 \%$ in X IPA 2 grade, $100 \%$ in X IPA 5 grade and X IPA 6 grade. While the smallest response of students to no. 13 whose contents stated the material in BAS relates to the daily life of $80 \%$ in X IPA 2 grade, $73 \%$ in X IPA 5 grade and $83 \%$ in $X$ IPA 6 grade. It is in accordance with the statement (Hosnan, 2014) stating the implementation of Discovery learning can encourage the students more active and learning process to be exciting [6].

\section{CONCLUSION}

The students' score of science process skills can be seen from the students' average of N gain in X IPA 2 grade was 0.61; the students' average of $\mathrm{N}$ gain in X IPA 5 grade was 0.70 and the students' average of $\mathrm{N}$ gain in X IPA 6 grade was 0.73 . The students' response of X IPA 2 grade was $89 \%$, X IPA 5 grade was $90 \%$ and X IPA 6 grade was $95 \%$.

\section{REFERENCES}

[1] Carin, A. A. (1993). Teaching Science through Discovery. New York: Mc Millan Publishing Company.

[2] Ciptaning, M. (2018). Implementasi Pembelajaran Discovery Learning Berbantuan QR Code Untuk Meningkatkan Keterampilan Proses Sains. Jurnal Pendidikan Biologi , 61-68.

[3] Ferdiansah, Z. (2014). Penerapan Model Pembelajaran Inkuiri Terbimbing Berbantuan Demonstrasi Untuk Meningkatkan Keaktifan dan Prestasi Belajar Siswa Kelas XI TKR 2 SMKN 1 Singosari Malang Tahun Ajaran 2014-2015. Malang: Universitas Kanjuruhan Malang.

[4] Hafid, W. (2017). Penerapan Model Discovery Learning Untuk Meningkatkan Pemahaman Konsep Cahaya dan Keterampilan Proses Sains Siswa Sekolah Dasar. Kendari: Universitas Halu Oleo Kendari.

[5] Hake, R. (1999). Retrieved January 23, 2019, from Physicsindiana.edu: http://www.physicsindiana.edu/sdi/Analyzing-Change-Gain.pdf
[6] Hosnan. (2014). Pendekatan Saintifik dan Kontekstual Dalam Pembelajaran Abad 21. Bogor: Ghalia Indonesia.

[7] Kemendikbud. (2016). Peraturan Menteri Pendidikan dan Kebudayaan Republik Indonesia Nomor 22 Tahun 2016 Tentang Standar Proses Pendidikan Dasar dan Menengah . Jakarta: Menteri Pendidikan dan Kebudayaan Republik Indonesia.

[8] Plomp, T \& Nieveen . (2010). An Introduction to Education Design Research. Netherlands: Netzodruk,Enschede.

[9] Riduwan. (2002). Skala Pengukuran Variabel - variabel Penelitian. Bandung: Alfabeta.

[10] Rizal, R. (2019). Implementasi Discovery Learning Untuk Meningkatkan Keterampilan Dasar Proses Sains Siswa SMA. Journal of Teaching and Learning Physics , 1-10.

[11] Sati, D. (2017). Penerapan Model Discovery Learning Untuk Meningkatkan Hasil Belajar Kognitif dan Keterampilan Proses Sains di Kelas VIIB SMP Negeri 10 Kota Bengkulu. Jurnal Pembelajaran Fisika, 73-78.

[12] Trilling, B \& Fadel, C. (2009). 21st Century Skills: Learning for Life in Our. United States of America: John Wiley \& Sons.

\section{AUTHORS}

First Author - Zefry Ardi Ferdiansah, Science Education, Post Graduate, State University of Surabaya, zefry.17070795008@mhs.unesa.ac.id

Second Author - Elok Sudibyo, Science Education, Post Graduate, State University of Surabaya,

elok.sudibyo@gmail.com

Third Author - Munasir, Science Education, Post Graduate, State University of Surabaya, munasir_physics@unesa.ac.id

Correspondence Author - Zefry Ardi Ferdiansah, Science Education, Post Graduate, State University of Surabaya, zefry.17070795008@mhs.unesa.ac.id 